\title{
THE WORLD OF ACADEMIA:
}

CULTURE, EDUCATION 


\section{THE WORLD OF ACADEMIA: CULTURE, EDUCATION}

Registration number: ЭЛ № ФС77-73671 dd. 28.09.2018.

Up to 28 September, 2018 the Journal was called

"News of Southern Federal University. Pedagogical Science". ISSN: 2658-6983.

The Joumal has been published since 1 June, 2007.

Founders:

Southern Federal University

Volga-Caucasian Department of the Russian Academy of Education

Editor in Chief

I.E. Kulikovskaya - Doctor of Pedagogics (habil.), professor, head of Pre-school Education dpt. of Southern Federal University, Head of South-Russian Research and Educational Centre of Spiritually-Moral Education of Children and Youth of Southern Federal University

\section{Deputy Chief Editors}

G.A. Berulava - Psychology Doctor (habil.), professor, academician of RAE, Rector of International Innovation University

V.I. Mareev - Doctor of Pedagogics (habil.), professor, Advisor of the Rector of Southern Federal University

International Editorial Board

I.V. Abakumova - Psychology Doctor (habil.), professor, correspondent member of RAE, Don State Technical University (Russia)

A.Yu. Belogurov - Doctor of Pedagogics (habil.), professor, Moscow State Institute of International Relations (University) of the Ministry of Foreign Affairs of the Russian Federation (Russia)

S.I. Beryl - Physical and Mathematical Sciences Doctor (habil.), professor, Pridnestrovian State University named after T.G. Shevchenko (Pridnestrovian Moldavian Republic)

N.M. Borytko - Doctor of Pedagogics (habil.), professor, Volgograd State University (Russia)

N.N. Veresov - Philosophy Doctor (habil.), professor, Monash University (Australia)

A.Ya. Danilyuk - Doctor of Pedagogics (habil.), professor, corresponding member of RAE, Moscow Pedagogical State University (Russia)

P.N. Ermakov - Biology Doctor (habil.), professor, academician of RAE, Southern Federal University (Russia)

A.K. Kiklevich - Philology Doctor (habil.), professor, University of Warmia and Mazury (Poland)

M.V. Korepanova - Doctor of Pedagogics (habil.), professor, Volgograd State Social and Pedagogical University (Russia)

I.B. Kotova - Psychology Doctor (habil.), professor, corresponding member of RAE, International Innovative University (Russia)

V.T. Kudryavtsev - Psychology Doctor (habil.), professor, Moscow State Psychological and Pedagogical University (Russia)

A.K. Kusainov - Doctor-engineer of Germany, Pedagogics Doctor (habil.), professor, winner of the State Award of the Republic of Kazakhstan, president of Academy of Pedagogical Sciences of Kazakhstan (Kazakhstan)

O.A. Omarov - Physical and Mathematical Sciences Doctor (habil.), professor, academician of RAE, Dagestan State University (Russia)

I.V. Robert - Doctor of Pedagogics (habil.), professor, academician of RAE, Institute of Education Management of RAE (Russia)

A.I. Savenkov - Doctor of Pedagogics (habil.), Psychology Doctor (habil.), corresponding member of RAE, Moscow City Pedagogical University (Russia)

N.K. Sergeyev - Doctor of Pedagogics (habil.), professor, academician of RAE, Volgograd State Social and Pedagogical University (Russia)

V.V. Serikov - Doctor of Pedagogics (habil.), professor, corresponding member of RAE, Institute of Strategy of Education Development of RAE (Russia)

Editorial Board

A.A. Andrienko - Candidate of Philology ( $\mathrm{PhD}$ equivalent), associate professor (Rostov-on-Don)

A.G. Bermus - Doctor of Pedagogics (habil.), professor (Rostov-on-Don)

V.I. Bondin - Doctor of Pedagogics (habil.), professor (Rostov-on-Don)

T.I. Vlasova - Doctor of Pedagogics (habil.), professor (Rostov-on-Don)

L.V. Goryunova - Doctor of Pedagogics (habil.), professor (Rostov-on-Don)

L.V. Goryunova - Doctor of Pedagogics (habil.), professor (Rostov-on-Don)
N.K. Karpova - Doctor of Pedagogics (habil.), professor (Rostov-on-Don)

G.V. Karantysh - Biology Doctor (habil.), associate professor (Rostov-on-Don)

A.M. Mendzheritsky - Biology Doctor (habil.), professor (Rostov-on-Don)

P.P. Pivnenko - Doctor of Pedagogics (habil.), professor (Rostov-on-Don)

E.I. Rogov - Doctor of Pedagogics (habil.), professor (Rostov-on-Don)

O.D. Fedotova - Doctor of Pedagogics (habil.), professor (Rostov-on-Don)
R.M. Chumicheva - Doctor of Pedagogics (habil.), professor (Rostov-on-Don)

The Journal is included in the List of Russian peer-reviewed scientific journals where main scientific results of theses for Degrees of Candidate of Science and Doctor of Science should be published

(Date of inclusion edition in the List 01.12.2015, № 678) 


\section{МИР УНИВЕРСИТЕТСКОЙ НАУКИ:}

КУЛЬТУРА, ОБРАЗОВАНИЕ 


\title{
МИР УНИВЕРСИТЕТСКОЙ НАУКИ: КУЛЬТУРА, ОБРАЗОВАНИЕ
}

Регистрационный номер: ЭЛ № ФС77-73671 от 28.09.2018.

До 28 сентября 2018 г. журнал назывался

"Известия Южного федерального университета. Педагогические науки». ISSN: 2658-6983.

Журнал издается с 1 июня 2007 г.

\author{
Учредители: \\ Южный федеральныи́ университет \\ Поволжско-Кавказское отАеление России́скои́ академии образования \\ Главныи́ реАактор \\ Куликовская Ирина ЭАуардовна - Аоктор педагогических наук, профессор, заведующая кафеАрой \\ Аошкольного образования Южного федерального университета, Аиректор Южно-России́ского научно- \\ образовательного центра Ауховно-нравственного воспитания детеи́ и молоАежи ЮФУ
}

\section{Заместители главного редактора}

Берулава Галина Алексеевна - доктор психологических наук, профессор, акалемик РАО, ректор МежАународного инновационного университета

Мареев Владимир Иванович - доктор педагогических наук, профессор, советник ректора Южного феАерального университета

МежАународная редакционная колпегия

Абакумова Ирина Владимировна - Аоктор психологических наук, профессор, член-корреспондент РАО, АОНской госуаарственныи́ технический университет (Россия)

Белогуров Анатолий Юльевич - Аоктор педагогических наук, профессор, Московский госуАарственный институт меЖАународных отношений (университет) Министерства иностранных Аел России́ской ФеАерации (Россия) Берил Степан Иораанович - Аоктор физико-математических наук, профессор, ПриАнестровский государственный университет им. Т.Г. Шевченко (Приннестровская Молдавская Республика)

Борытко Николай Михаи́лович - Аоктор педагогических наук, профессор, Волгоградский госуАарственныи́ университет (Россия)

Вересов Николай Николаевич - Аоктор философских наук, профессор, Университет Монаш (Австра^ия)

Аанилюк Алексанар Ярославович - Аоктор педагогических наук, профессор, член-корреспондент РАО, Московский педагогический государственный университет (Россия)

сковский пеАагогический госуАарственный университет (Россия) Ермаков Павел Нико

Книверситет (Россия) верситет (Польша)

Корепанова Марина Васипьевна - доктор педагогических наук, профессор, Волгоградский государственный социально-педагогический университет (Россия)

Котова Изабела Борисовна - доктор психологических наук, профессор, член-корреспондент РАО, МежАунароАный инновационный университет (Россия)

Куарявцев Владимир Товиевич - доктор психологических наук, профессор, Московскии́ госуаарственныи́ психолого-педагогический университет (Россия)

Кусаинов Аскарбек Кабыкенович - Аоктор-инженер Германии, Аоктор педагогических наук, профессор, Кусаинов Аскарбек Кабыкенович - Аоктор-инженер Германии, Аоктор педагогических наук, профессор,
лауреат Государственной премии Республики Казахстан, президент Академии педагогических наун Казахстана
(Казахстан) (Казахстан)

Омаров Омар Апиевич - Аоктор физико-математических наук, профессор, акаАемик РАО, Аагестанскии́ госуАарственныи́ университет (Россия)

Роберт Ирэна Веньяминовна - доктор педагогических наук, профессор, академик РАО, Институт управления образованием РАО (Россия)

Савенков Алексанар Ипьич - доктор педагогических наук, Аоктор психологических наук, член-корреспонАент РАO, Московскии́ городской педагогический университет (Россия)

Сергеев Николаи́ Константинович - Аоктор пеАагогических наук, профессор, академик РАО, ВолгограАскии́ госуаарственныи́ социально-пеАагогический университет (Россия)

Сериков Владислав Владиславович - АоКтор педагогических наук, профессор, член-КорреспонАент РАО, ИНститут стратегии развития образования РАО (Россия)

Реаакционныи́ совет

Андриенко Анна Александровна - кандидат филологических наук, Аоцент (Ростов-на-Аону) Бермус Алексанар Григорьевич - Аоктор педагогических наук, профессор (Ростов-на-Аону) Бонаин Виктор Иванович - Аоктор педагогических наук, профессор (Ростов-на-Аону)

Власова Татьяна Ивановна - доктор педагогических наук, профессор (Ростов-на-Аону)

Горюнова Аипия Васильевна - Аоктор педагогических наук, профессор (Ростов-на-Аону)

Карпова Наталья Константиновна - Аоктор педагогических наук, профессор (Ростов-на-Аону)

Карпова Наталья Константиновна - Аоктор педагогических наук, профессор (Ростов-на-Аону
Карантыш Галина Владимировна - доктор биологических наук, доцент (Ростов-на-Аону)

Карантыш Галина Владимировна - Аоктор биологических наук, Аоцент (Ростов-на-Аону)
Менджерицкий Александр Маркович - Аоктор биологических наук, профессор (Ростов-на-Аону)

Менажерицкии́ Александр Маркович - Аоктор биологических наук, Профессор (Ростов-
Пивненко Петр Петрович - Аоктор педагогических наук, профессор (Ростов-на-Аону)

Рогов Евгении́ Иванович - Аоктор педагогических наук, профессор (Ростов-на-Аону)

Федотова Ольга Амитриевна - Аоктор педагогических наук, профессор (Ростов-на-Аону)

Чумичева Раиса Михайловна - доктор педагогических наук, профессор (Ростов-на-Аону)

Журнал включен в Перечень российских рецензируемых научных журналов, в которых Аолжны быть опубликованы основные научные результаты Аиссертации

на соискание ученых степеней Аоктора И кандиАата наук

(Аата включения изАания в перечень 0I.12.2015, № 678) 


\section{ОБЩАЯ ПЕААГОГИКА, ИСТОРИЯ ПЕААГОГИКИ И ОБРАЗОВАНИЯ}

Куликовская И.Э., Князева Л.В.

КОЛЛАБОРАТИВНОЕ ОБУЧЕНИЕ ДЕТЕЙ В ДОШКОЛЬНОЙ ОРГАНИЗАЦИИ:

ПРОСТРАНСТВО ВЗАИМОДЕЙСТВИЯ..

Чумичева Р.М., Штайдо Т.С., Беспалая В.А.

ИНТЕГРАТИВНЫЙ ПОДХОД В УКРЕПЛЕНИИ ЗДОРОВЬЯ ДЕТЕЙ ДОШКОЛЬНОГО ВОЗРАСТА

В ДОШКОЛЬНОЙ ОБРАЗОВАТЕЛЬНОЙ ОРГАНИЗАЦИИ.

Шостак Е.В., Донской Д.ю.

ПРИМЕНЕНИЕ ПРОЕКТНО-ИЗОБРЕТАТЕЛЬСКОЙ ДЕЯТЕЛЬНОСТИ

В РАЗВИТИИ ТВОРЧЕСКОГО МЫШЛЕНИЯ ОБУЧАЮЩИХСЯ ТЕХНОПАРКОВ

\section{КОРРЕКЦИОННАЯ ПЕААГОГИКА}

Колодяжная Т.П., Березовская Р.В., Вихарева М.Б., Малова Л.В., Рыбалко В.Е.

ПРОФИЛАКТИКА ДИСГРАФИИ У ДЕТЕЙ МЛАДШЕГО ШКОЛЬНОГО ВОЗРАСТА

\section{ТЕОРИЯ И МЕТОАИКА ФИЗИЧЕСКОГО ВОСПИТАНИЯ, СПОРТИВНОЙ ТРЕНИРОВКИ, ОЗАОРОВИТЕЛЬНОЙ И АДАПТИВНОЙ ФИЗИЧЕСКОЙ КУЛЬТУРЫ}

Наумов И.В.

ФИЗИЧЕСКАЯ КУЛЬТУРА И СПОРТ КАК УСЛОВИЕ ФОРМИРОВАНИЯ

ЧЕЛОВЕЧЕСКОГО КАПИТАЛА СТУДЕНТОВ.

\section{TEОРНЯ И МЕТОАИКА ПРОФЕССИОНАЛЬНОГО ОБРАЗОВАНИЯ}

Цянь Мэнсинь, Романенко Н.М.

СПЕЦИФИКА И ТЕНДЕНЦИИ ПОДГОТОВКИ ПРОФЕССИОНАЛЬНЫХ КАДРОВ

В ВУЗАХ КИТАЙСКОЙ НАРОДНОИ РЕСПУБЛИКИ

Толстихина Е.В.

РАЗВИТИЕ ЧЕЛОВЕЧЕСКОГО КАПИТАЛА И SOFТ SKILLS СТУДЕНТОВ ВУЗОВ

СРЕДСТВАМИ ВИРТУАЛЬНОЙ МЕЖДУНАРОДНОЙ АКАДЕМИЧЕСКОЙ МОБИЛЬНОСТИ

(В КУРСЕ ДИСЦИПЛИНЫ «ИНОСТРАННЫЙ ЯЗЫК (АНГЛИЙСКИЙ)»)

Сагайдачная Е.Н., Мартыненко Е.В.

О НЕКОТОРЫХ ОСОБЕННОСТЯХ ОБУЧЕНИЯ СТУДЕНТОВ ЭКОНОМИЧЕСКИХ

СПЕЦИАЛЬНОСТЕЙ В МАГИСТРАТУРЕ В ОНЛАЙН-РЕЖИМЕ

Мартыненко Е.В.

НЕКОТОРЫЕ ПРОБЛЕМЫ ОНЛАЙН-ОБРАЗОВАНИЯ

Натуркач М.B.

МЕДИАДИСКУРС В ИНФОРМАЦИОННОМ ПРОСТРАНСТВЕ

И НЕОБХОДИМОСТЬ РАЗВИТИЯ МЕДИАДИСКУРСИВНОЙ КОМПЕТЕНЦИИ СТУДЕНТОВ 90

\section{ОБЩАЯ ПСИХОАЛГИЯ, ПСИХОЛОГИЯ АИЧНОСТИ, ИСТОРИЯ ПСИХОЛОГИИ}

Abakumova I.V., Godunov M.V., Grishina A.V.

STAGES IN MAKING A CHOICE OF MEANING

\section{ПЕААГОГИЧЕСКАЯ ПСИХОЛОГИЯ}

Гадаборшева 3.И., Рогов Е.И.

ТРАНСФОРМАЦИЯ ПРОФЕССИОНАЛЬНЫХ ПРЕДСТАВЛЕНИЙ

В УСЛОВИЯХ ДИСТАНЦИОННОЙ ОРГАНИЗАЦИИ ДЕЯТЕЛЬНОСТИ

НАШИ АВТОРЫ 


\section{GENERAL PEDAGOGICS; THE HISTORY OF PEDAGUGICS AMD EDUCATIOH}

Kulikovskaya Irina E., Knyazeva Lyudmila V.

TEACHING CHILDREN COLLABORATIVELY IN A PRESCHOOL ORGANIZATION:

SPACE FOR INTERACTION.....

Chumicheva Raisa M., Shtaydo Tatiana S., Bespalaya Vera A.

INTEGRATTVE APPROACH TO IMPROVING THE HEALTH OF CHILDREN

IN A PRESCHOOL EDUCATIONAL ORGANIZATTON

Shostak Egor V., Donskoy Dmitry Yu.

APPLICATION OF PROJECT-BASED AND INVENTIVE ACTIVITY IN DEVELOPMENT

OF CREATIVE THINKING OF TECHNOPARK STUDENTS

\section{CORRECTIOHAL PEDAGOGY}

Kolodyazhnaya Tatiana P., Berezovskaya Regina V.,

Vikhareva Maria B., Malova Lilia V., Rybalko Victoria E.

PREVENTION OF DISGRAPHY IN CHILDREN OF PRIMARY SCHOOL AGE

THEORY AND METHODS OF PHYSICAL EDUCATIOH, SPORTS TRAIMIMG, HEALTH-IMPROVING AND ADAPTIVE PHYSICAL CULTURE

Naumov Igor V.

PHYSICAL CULTURE AND SPORTS AS A CONDITION

FOR DEVELOPING STUDENTS ${ }^{\prime}$ HUMAN CAPITAL

\section{THEORY AND METHODS OF PROFESSIOHAL EDUCATION}

Qian Mengxin, Romanenko Nadezhda M.

SPECIFICS AND TRENDS OF PROFESSIONAL PERSONNEL TRAINING

AT UNIVERSITIES OF THE PEOPLE'S REPUBLIC OF CHINA

Tolstikhina Elena V.

DEVELOPMENT OF HUMAN CAPITAL AND SOFT SKILLS OF UNIVERSITY STUDENTS

BY MEANS OF VIRTUAL INTERNATIONAL ACADEMIC MOBILITY

(WITHIN THE COURSE «FOREIGN LANGUAGE -ENGLISH»)

Sagaidachnaya Elizaveta N., Martynenko Elena V.

ON SOME FEATURES OF TEACHING MASTER'S DEGREE STUDENTS IN ECONOMICS

IN THE ONLINE MODE

Martynenko Elena V.

SOME PROBLEMS OF ONLINE EDUCATTON

Naturkach Mikhail V.

MEDIA DISCOURSE IN THE INFORMATION SPACE AND THE NEED

TO DEVELOP STUDENTS' ${ }^{\prime}$ MEDIA DISCOURSE COMPETENCE.

\section{GeMERAL PSYCHOLOGY, PERSOMAL PSYCHOLOGY AMD THE HISTORY OF PSYCHOLOGY}

Abakumova Irina V., Godunov Mikhail V., Grishina Anastasia V.

STAGES IN MAKING A CHOICE OF MEANING

\section{PEDAGOHICAL PSYCHDLOGY}

Gadaborsheva Zarina I., Rogov Evgeniy I.

TRANSFORMATION OF PROFESSIONAL IDEAS IN THE CONTEXT OF REMOTE ACTIVITY 
Абакумова Нрина Владимировна,

Годунов Михаип Викторович,

Гришина Анастасия Васильевна

\section{ЭТАПЫ ОСУЩЕСТВАЕНКЯ}

\section{СМЫС ОВОГО ВЫБОРА}

Рассматривается психологическая проблематика смыслового выбора, который не является классическим случаем логического выбора. В основе смыслового выбора лежит механизм генерации личностного смысла, учитывающего разноуровневые контексты суб́ъекта жизнедеятельности. В этом отличие от операционального смысла, являющегося формальньм образом ситуационного реагирования и психического отражения во взаимодействиях. Этапы осушествления смыслового выбора включают децентрацию смыслов, генерализацию смыслов и инициацию смыслов. Смысловая децентрация представляется этапом зарождения личностного смысла на периферии смысловой системы переживающего субъекта. В ходе смысловой генерализации происходит выделение личностного смысла и перевод его на субъективно значимые позиции среди имеющихся смысловых образований. На этапе смысловой инициации осуществляется оценивающий выбор среди значимых смысловых конструктов, проводимый по иерархии внутренних критериев. Знание особенностей этапов смыслового выбора позволяет более качественно исследовать смысловую регуляцию деятельности современного человека.

Гадаборшева Зарина Исранповна,

\section{Рогов Евгений Иванович}

ТРАНСФОРМАЦКЯ ПРОФЕССНОНАМЬНЫХ

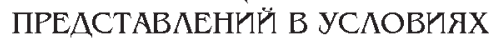

АКСТАНЦИОННОЙ ОРГАНИЗАЦИИ

АЕЯТЕ АЬНОСТИ

Цифровизация современного мира, ведущая к постоянному увеличению числа сотрудников различных организаций, выполняющих свои функции удаленно, воспринимается большинством аналитиков как однозначно положительная трансформация, способствующая прогрессу социума. В то же время проблема отражения данного процесса на становлении внутреннего мира суб́ъекта деятельности, анализ дальнейших перспектив развития его профессионализма остаются малоисследованными. В данной работе рассматриваются особенности профессиональных представлений как индикаторов профессионализма в условиях дистанционной организации профессиональной деятельности. Дистанционная организация труда порождает многочисленные модификации в современной профессиональной деятельности, изменяя сложившиеся отношения, профессиональные установки людей, перешедших на «удаленную» работу. Их взгляды и предпочтения существенно отличаются от таковых у их предшественников, так как погружение в виртуальную среду устраняет подлинную, изначально данною природой пространственную границу реальности. Многие источники отражают, с одной стороны, тенденцию к снижению интенсивности взаимодействия людей из-за расширения их общения с различными виртуальными собеседниками, а с другой - поиск различных средств визуализации для создания адекватных образов в сознании этих собеседников. Так, передача эмоциональных состояний визуализировалась в различных графических объектах. Показано, что воссоздание профессиональных представлений субъекта определяется сформированными у него ранее установками и стереотипами, особенностями стиля виртуальной идентичности, уровнем сетевого подражания и аддикции, эмпатическими тенденциями и особенностями рефлексивных механизмов. 


\section{Колодяжная Татьяна Павповна, \\ Березовская Регина Васильевна, Вихарева Мария Борисовна, \\ Мапова Пилия Впадимировна, \\ Рыбапко Виктория Евгеньевна}

\section{ПРОФЮААКТЯКА АНСГРАФНИ \\ У АЕТЕН̆ МАААШЕГО}

ШКОАЬНОГО ВОЗРАСТА

В статье представлен анализ теоретических и практических исследований по изучению проблемы профилактики дисграфии у младших школьников. Авторами рассматриваются возможности и принципиальное отличие нейропсихологического подхода в работе по предупреждению дисграфии у младших школьников. Также освещен вопрос о возможностях и преимуществах IT-технологий. Представлено описание логопедической программы коррекционно-развивающей и профилактической направленности.

Купиковская Ирина Эдуардовна,

Князева Пюдмила Вячеспавовна

КОА АБОРАТYВНОЕ ОБУЧЕНКЕ АЕТЕЙ

В АОШКОАЬНОЙ ОРГАННЗАЦИИ:

ПРОСТРАНСТВО ВЗАИМОАЕЙСТВНЯ

В статье раскрыта актуальность организации коллаборативного обучения детей, связанная с изменениями мирового образовательного пространства. Формируется новая стратегия образования в соответствии с реалиями современного общества, такими как становление VUCA-мира, основными характеристиками которого являются нестабильность, неопределенность, сложность и неоднозначность. В таком мире значимой ценностью становится образование в течение всей жизни, а значит, необходимо постоянно учиться чему-то новому. Авторы рассматривают навыки XXI в., такие как умение критически мыслить, вступать в коммуникации, коллаборации и креативно решать возникающие перед человеком задачи. Эти 4 К-компетенции начинают формироваться уже в дошкольном возрасте. Акцент сделан на коллаборативном обучении детей, так как в нем, в отличие от индивидуального обучения, все участники делятся своими ресурсами и находками, спрашивают друг друга, отслеживают ход и результаты деятельности другого. Каждый обучающийся становится успешным членом сообщества, ориентированного на познание какой-либо сферы жизни и достижение продуктивного результата. В статье представлена авторская модель, нацеленная на организацию совместной деятельности дошкольников и педагогов по овладению компетенциями, приобретению опыта деятельности, применения знаний в повседневной жизни и формированию у них мотивации познания окружающего мира в процессе активного поиска информации, обсуждения и понимания смыслов.

\section{Мартыненко Епена Владимировна}

\section{НЕКОТОРЫЕ ПРОБАЕМЫ}

ОНААЙН-ОБРАЗОВАНКЯ

В статье обозначены и проанализированы некоторые проблемы онлайн-образования. Рассмотрены проблемы в терминологии онлайн-образования и возможные риски, стоящие за онлайн-формой. Отдельное внимание сфокусировано на высшем образовании и проблемах онлайн-обучения в его рамках. Проведен опрос студентов второго курса, выявляющий их отношение к онлайн-образованию, а также приведен список проблем, с которыми студенты столкнулись при онлайн-обучении, полученный в ходе исследования. При анализе результатов исследования применялся метод статистического анализа количественных и процентных характеристик. 


\section{Натуркач Михаип Васильевич}

\section{МЕАИААИСКУРС В ИНРОРМАЦИОННОМ ПРОСТРАНСТВЕ И НЕОБХОАКМОСТЬ РАЗВКТИЯ МЕАКААКСКУРСКВНОЙ КОМПЕТЕНЦИҢ СТУАЕНТОВ}

В статье автор определяет место медиадискурса в современном информационном пространстве, указывая его постоянного влияние на содержание жизнедеятельности общества, власти и граждан. Методологически рассмотрены термины «информационное пространство», «информационное общество», «медиадискурс», история их возникновения и результат научного осмысления. Употребление данных терминов началось еще в 1960-х гт. в японских и американских исследованиях, посвященных выявлению роли знаний в прогрессе человечества (Ю. Хаяши, Т. Умесао и Ф. Махлуп). Информационное пространство, в ходе освоения которого формируется медиадискурсивная компетентность, автор представляет в качестве совокупности информационных ресурсов, информационных систем и коммуникационной среды (каналов). Явление медиадискурса нацеливает вузы и институты на развитие у студентов медиадискурсивной компетенции. Автором сделан хороший задел и создана содержательная база для формирования медиадискурсивной компетентности личности. В заключение указано, что информационное пространство несет крайне важную функциональную нагрузку, формируя медиадискурсивную компетентность личности.

\section{Наумов Нгорь Владимирович}

\section{РИЗНЧЕСКАЯ КУМЬТУРА И СПОРТ}

КАК УС ОВИЕ ТОРМИРОВАНИЯ

\section{ЧЕ АОВЕЧЕСКОГО КАПНТААА СТУАЕНТОВ}

В статье рассматривается роль физической активности в процессе формирования человеческого капитала студентов вуза средствами образования. Анализ эмоционального опыта студентов во время занятий физической культурой и спортом основан на теории контрольной ценности эмоций достижения. Цель исследования состояла в проверке предположения о том, что специально созданные условия для занятий физической культурой и спортом могут позитивно повлиять на формирование человеческого капитала студентов. Исследование базировалось на оценке эмоций контроля и достижений студентов Южного федерального университета, пережитых ими в курсе дисциплины «Физическая культура и спорт». Результаты показали, что, в частности, положительные аффекты физической активности студентов могут предсказывать эффективность их академического поведения и результатов.

\section{Сагайдачная Епизавета Николаевна, Мартыненко Елена Владимировна}

\section{O НЕКОТОРЫХ ОСОБЕННОСТЯХ \\ ОБУЧЕНИЯ СТУАЕНТОВ \\ ЭКОНОМИЧЕСКИХ СПЕЦИАЛЬНОСТЕЙ \\ В МАГИСТРАТУРЕ В ОНААЙНН-РЕЖКМЕ}

Цифровизашия обучения не только показала проблемные моменты современного образования, но и открыла новые возможности использования цифрового обучения, в частности обучения в магистратуре в онлайн-режиме, что является крайне значимым на фоне пандемии, при снижении общего числа обучающихся, сбоях в обучении по всему миру. Современная образовательная траектория призвана готовить студентов к гибкости в получении новых знаний и умений, в смене профессиональной деятельности, открывая «цифровым аборигенам» новое поле деятельности. В раб́оте рассмотрены некоторые особенности новой образовательной парадигмы, в частности изменение роли преподавателя в новой цифровой среде. Целью исследования было выявление потенциальных 
студентов онлайн-магистратуры, а также обобщение личностньх оценочных суждений студентов об онлайн-обучении в магистратуре. Проведенный опрос 100 студентов экономических специальностей «Менеджмент и предпринимательство», «Экономика и финансы» выявил две основные группы потенциальных студентов магистратуры: студенты-бакалавры и работающие молодые люди. Был отмечен ведущий тип мотивации этой группы потенциальных магистрантов - мотивация личного престижа. Результаты данного исследования могут оказаться полезными методистам, педагогам, руководителям в области высшего образования как опора при создании успешньх онлайн-курсов для магистратуры экономических специальностей.

\section{Толстихина Елена Владимировна}

\section{РАЗВНTИЕ ЧЕ $А$ ОВЕЧЕСКОГО \\ КАПИТААА И SOFT SKILLS СТУAЕНTOB \\ ВУЗОВ СРЕАСТВАМИ ВНРТУААЬНОЙ \\ МЕЖАУНАРОАНОЙ АКААЕМИЧЕСКОЙ \\ МОБҮ МЬНОСТИ (В КУРСЕ АКСЦИПАННЫ \\ "ҮНОСТРАННЫЙ ЯЗЫК (АНГАҮЙСКҮҢ̆)")}

В ответ на вызовы 2020-2021 гт. образование претерпевает трансформации форм и содержания обучения в стремлении сохранить качество развития человеческого капитала студентов. Одна из сложностей, с которыми столкнулись все высшие учебные заведения, - сохранение международной академической мобильности студентов как способа развития soft skills и коммуникативного навыка. В статье обсуждается опыт Южного федерального университета по внедрению смешанного формата обучения с применением международной виртуальной, или онлайн-мобильности студентов в рамках курса «Иностранный язык (английский)», связанного с развитием человеческого капитала студентов и коммуникативной компетенции. Теория человеческого капитала выступает ключевой в определении образовательных целей, а уровень владения английским языком определяется как необходимый для развития soft skills XXI в. Также приводятся результаты академических достижений студентов после обучения в смешанном формате.

\section{Цянь Мэнсинь}

\section{Романенко Надежда Михайповна}

\section{СПЕЦИФИКА И ТЕНАЕНЦИЯ ПОАГОТОВКИ \\ ПРОФЕССКОНААЬНЫХ КААРОВ В ВУЗАХ \\ КЮТАЙСКОЙ НАРОАНОЙ РЕСПУБ АЮКК}

В статье авторы представили анализ специфики и тенденций подготовки профессиональных кадров в вузах Китайской Народной Республики. Идет разговор о становлении национальной системы подготовки профессиональных кадров в учебных заведениях Китая, который прошел, по сути, уникальный путь. Проанализированы и учтены многообразные аспекты профессиональной подготовки. Определены причины, требующие устранения в системе профессиональной подготовки Китая. Авторы отмечают 2015 г. как новый этап модернизации и реформирования высшего образования в КНР, когда заработал государственный проект «Университеты и дисциплины мирового класса» (шуани-лю, «Дважды первых»), ставящий перед собой амбициозную цель - вывести китайское высшее образование к 2050 г. на позиции безусловного мирового лидера. В статье подробно описаны формы производственно-образовательного и научного партнерства: научные парки (технопарки) при университетах, совместные исследовательские и технологические центры, предприятия, созданные университетами. В рамках исследуемой проблемы в контексте проекта «Один пояс - один путь» авторы отмечают проводимую в последнее время китайским правительством в области образования политику сохранения и привлечения внимания к профессиональному культурному наследию. 
Чумичева Раиса Михайловна.

Штайдо Татьяна Сергеевна.

Беспалая Вера Александровна

ИНТЕГРАТИВНЫЙ ПОАХОА

В УКРЕП АННИ ЗАОРОВЬЯ АЕТЕЙ

АОШКОАЬНОГО ВОЗРАСТА

В АОШКОАЬНОЙ ОБРАЗОВАТЕАЬНОЙ

ОРГАНИЗАЦИИ

Статья посвящена внедрению интегративного подхода в практику дошкольньх образовательньх учреждений с целью создания в них здоровьесберегающего образовательного пространства. Для этого, по мнению авторов, дошкольная педагогика должна объединить под одной крышей педагогику, медицину и психологию. Представлены результаты проведения оздоровительной программы «За здоровьем в детский сад», демонстрирующие положительный эффект в деле формирования нового направления в дошкольном образовании - здоровьесозидающей педагогики.

Шостак Егор Ваперьевич,

Донской Дмитрий Юрьевич

ПРИМЕНЕНИЕ ПРОЕКТНО-

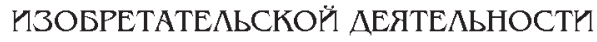

В РАЗВИТИИ ТВОРЧЕСКОГО МЫШ КЕНИЯ

ОБУЧАЮЩИХСЯ ТЕХНОПАРКОВ

В статье рассмотрено становление проектно-изобретательской деятельности в мировом и отечественном образовании. Описана значимость развития технического творчества в условиях дополнительного образования. Обосновывается применение проектно-изобретательской деятельности в развитии творческого мышления обучающихся в дополнительном образовании на примере использования программы «Аэроквантум» (дроностроение и дронопроектирование). Описывается разработанная методика, направленная на формирование универсальных и предметных компетенщии и ориентированная на расширение образованности и кругозора обучающегося, с включением проектно-изобретательной деятельности со всеми стадиями ее реализации - от зарождения идеи до воплощения ее в действительность. Описывается әкспериментальная программа, разработанная на модульной основе. Итоговая цель данного исследования сформировать у обучающихся универсальные и предметные компетенции по основным направлениям: программирование микроконтроллеров, летная эксплуатация беспилотных авиационных систем и др. В результате педагогического эксперимента на данном этапе решены следующие задачи: разработан, с последующим апробированием, проект по направлению «Дроностроение» $\mathrm{c}$ использованием программы «Аәроквантум»; рассмотрена актуальность освоения технологии обучения проектно-изобретательской деятельности в проектной группе, основная идея которой заключается в самостоятельном распределении роли обучающегося и функционала его в команде. 


\section{READ III ISSUE}

\section{Abakumova Irina V., Godunov Mikhail V. Grishina Anastasia V.}

\section{STAGES IN MAKING A CHOICE OF MEANING}

Key words: meaning, choice of meaning, meaning

decentralization, meaning generalization, mean-

ing initiation.

The article deals with certain psychological problems of choice of meaning which does not refer to a classical case of logical choice. The choice of meaning is based on the mechanism of generating personal senses, taking into account the multi-level contexts of the subject of life. It differs from the operational sense which is a formal image of situational response and mental reflection in interactions. The stages of making a meaning choice include decentralization, generalization and initiation of meanings. Decentralization is represented as a stage of the origin of personal senses on the periphery of the semantic system of the experiencing subject. In the course of meaning generalization, personal meaning is isolated and transferred to subjectively significant positions among the existing sense-making formations. The evaluative choice is made at the stage of meaning initiation among significant meaning constructs, carried out according to the hierarchy of internal criteria. Knowing the features of the stages of this choice enables to study regulation of sense-making activity of a modern person more thoroughly.

\section{Chumicheva Raisa M., Shtaydo Tatiana S., \\ Bespalaya Vera $\mathbf{A}$.}

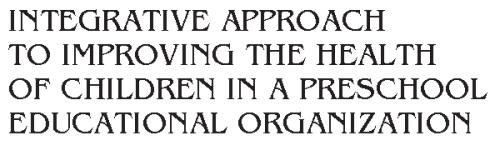

Key words: integrative approach, preschool educational institutions, physical health of children, health-improving pedagogy.

The article is devoted to introduction of the integrative approach into practice of preschool educational institutions in order to create a health-saving educational space. According to the authors, for this goal preschool pedagogy should combine pedagogy, medicine and psychology. The authors share results of the wellness program "For health in kindergarten", demonstrating a positive new direction in preschool education - health-improving pedagogy.

\section{Gadaborsheva Zarina I., Rogov Evgeniy I.}

TRAYSFORMATIOY OF PROFESSIONAL

IDEAS IY THE CONTEXT

OF REMOTE ACTIVITY

Key words: psychology of the virtual environment,

remote organization of activity, professional ideas,

visualization, virtual identity, network imitation,

network addiction.

Digitalization of the modern world, leading to the constant increase in the number of employees of different organizations working remotely, is perceived by most analysts as a positive transformation that contributes to the progress of society. At the same time, the problem of the influence of this process on the inner world of employees and analysis of further prospects for his professionalism development remain poorly studied. The article considers some peculiarities of professional ideas as indicators of professionalism in the conditions of remote professional activity. Distant 
work generates numerous modifications in modern professional activity, changing the well established relationships, professional attitudes of people who have made a shift to the "remote mode" of work. Their views and preferences differ significantly from their predecessors, as the immersion into the virtual environment eliminates the real spatial boundary of reality originally given by nature. Many sources single out, on the one hand, the tendency to reduce the intensity of human interaction due to the growth in "communication" with various virtual "interlocutors"; on the other, researchers mention intense search for various visualization tools to create adequate images in the minds of these interlocutors. Thus, emotional states get visualized in various graphic objects. The authors claim that reconstruction of professional ideas of a person is determined by previously formed attitudes and stereotypes, features of the style of virtual identity, the level of network imitation and addiction, empathic tendencies and peculiarities of reflexive mechanisms.

\section{Kolodyazhnaya Tatiana P., Berezovskaya Regina V., Vikhareva Maria B., Malova Lilia V., Rybalko Victoria E.}

\section{PREVENTIOY OF DISGRAPHY}

\section{IY CHILDREY OF PRIMARY SCHOOL AGE}

Key words: written speech; dysgraphia; primary school age; neuropsychological approach; IT-technologies.

This article analyses theoretical and practical research into the problem of preventing writing disorders in primary schoolchildren with dysgraphia. The authors discuss the possibilities and fundamental features of the neuropsychological approach in the work on prevention of dysgraphia in primary schoolchildren. The issue of the opportunities provided and advantages of IT technologies is also highlighted. The paper presents description of the speech therapy program of correctional, developmental and preventive type.

\section{Kulikovskaya Irina E., Knyazeva Lyudmila $\mathrm{V}$.}

\section{TEACHIYG CHILDREY COLLABORATIVELY \\ IN A PRESCHOOL ORGANIZATION: SPACE FOR INTERACTIOY}

Key words: collaborative learning of preschool children, collaborative environment, collaboration, cooperation, learning in cooperation.

The article reveals the relevance of collaborative learning for children, associated with changes in the world educational space. A new education strategy is being formed in accordance with the realities of modern society, such as the formation of the VUCA-world, the main characteristics of which are instability, uncertainty, complexity and ambiguity. In such a world, lifelong education becomes a significant value, which means that it is necessary to constantly learn something new. The authors consider the skills of the XXI century, such as the ability to think critically, engage in communication, collaboration and creatively solve problems that arise before a person. These $4 \mathrm{C}$ competencies begin to be formed already at preschool age. The emphasis is placed on collaborative teaching of children, since in it, unlike individual learning, all participants share their resources and findings, ask each other, track the progress and results of other participants' activities. Each student becomes a successful member of a community focused on learning about any sphere of life and achieving a productive result. The article presents the author's model aimed at organizing joint activities of preschoolers and teachers to master competencies, gain useful experience, apply knowledge to everyday life and boost motivation to learn about the world around by actively searching for information, discussing and understanding meanings. 


\section{Martynenko Elena $\mathrm{V}$.}

\section{SOME PROBLEMS OF ONLINE EDUCATION}

Key words: online education, terminology of online learning, risks of online education, problems of higher education in the digital environment.

The article identifies and analyzes some of the problems of online education. The paper raises the issues connected with terminology of online education and possible risks behind the online mode. Special attention is paid to higher education and the problems of online learning within its framework. The author shares results of the survey of 2nd year students that reveals their attitude to online education, and a list of problems that students encountered in online learning. When analyzing the study findings, the method of statistical analysis of quantitative and percentage characteristics was used.

\section{Naturkach Mikhail V.}

MEDIA DISCOURSE IY THE IYFORMATION

SPACE AYD THE NEED TO DEVELOP

STUDENTS' MEDIA DISCOURSE COMPETENCE

Key words: information space, information envi-

ronment, discourse, media discourse, media text, mass media, media education.

The article considers the place of media discourse in the modern information space, pinpointing its constant influence on the content of life of society, authorities and citizens. The author methodologically analyses the terms "information space", "information society", "media discourse", the history of their origin and scientific understanding. The researcher gives outline to the current state and approaches towards mass media and information space, specifically indicating the early use of these terms in the 1960s in Japanese and American studies devoted to identifying the role of knowledge in the progress of mankind (Yujiro Hayashi, Tadao Umesao and Fritz Machlup). The author defines the notion of information space where media discourse competence is formed as a set of information resources, information systems and communication environment (channels). The author outlines substantial framework and creates the content background for developing the media discourse competence of a person. In conclusion, the article emphasizes the fact that the specific status of information space is extremely important both functionally and instrumentally for developing the media discourse competence of an individual.

\section{Naumov Igor $\mathbf{V}$.}

PHYSICAL CULTURE AYD SPORTS

AS A CONDITION FOR DEVELOPING STUDENTS' HUMAY CAPITAL

Key words: student human capital, physical culture, emotions and academic achievements, physical activity of students.

The article reveals the role of physical activity in developing human capital of university students by educational means. Analysis of the emotional experience of students during physical education and sports is based on the theory of the control value of the emotions of achievement. The purpose of this study is to prove the assumption that specially created conditions for physical education and sports can affect positively the formation of students' human capital. The study was carried out via evaluation of the emotions of control and achievements experienced by in the course of doing physical culture and sports at Southern Federal University. 
The research outcomes show that positive effects of students' physical activity can predict effectiveness of their academic performance and results.

Qian Mengxin, Romanenko Nadezhda M.

\author{
SPECIFICS AND TRENDS \\ OF PROFESSIONAL PERSONYEL TRAINING \\ AT UYIVERSITIES OF THE PEOPLE'S \\ REPUBLIC OF CHINA
}

Key words: training of professional personnel,

universities of the People's Republic of China,

national system of training of professional person-

nel, partnership, “One Belt, one Road”.

In the article, the authors analyze the specifics and trends of training professional personnel at universities of the People's Republic of China. There is a conversation about the national system of training professional personnel in educational institutions in China which has, in fact, follows its unique path. Various aspects of professional training are analyzed and taken into account. The reasons that need to be eliminated in the system of vocational training in China are identified. The authors note 2015 as a new stage of modernization and reform of higher education in the People's Republic of China when the state project "World-class Universities and Disciplines» (Shuang-i - liu, «Twice the first»)" was launched, setting an ambitious goal: to bring Chinese higher education to the position of the undisputed world leader by 2050 . The article describes in detail the forms of industrial, educational and scientific partnership: scientific parks (technoparks) at universities, joint research and technology centers, and enterprises created by universities. Within the framework of the studied problem in the context of the "One Belt, One Road" project, the authors note the recent policy of the Chinese government in the field of education to preserve and attract attention to professional cultural heritage.

\title{
Sagaidachnaya Elizaveta N., Martynenko Elena V.
}

\section{ON SOME FEATURES OF TEACHING \\ MASTER'S DEGREE STUDENTS \\ IN ECONOMICS IN THE ONLINE MODE}

Key words: digital education, online learning,

motivation, online Master's degree, the role of a teacher.

Digitalization of education has not only shown the problematic aspects of modern education, but also opened up new opportunities for using digital learning, in particular, Master's degree training in online mode. This is extremely significant against the background of the pandemic, with a decrease in the total number of students and learning failures around the world. The modern educational trajectory is designed to prepare students for flexibility in obtaining new knowledge and skills, the ability to change professional activities, opening up a new field of activity for "digital natives". The paper considers some features of the new educational paradigm, in particular, changes in the role of a teacher in the new digital environment. The purpose of the study is to identify potential students of online Master's degree program, as well as to generalize students' personal judgments about taking a Master's degree course online. The survey of 100 students who major in Economics ("Management and Entrepreneurship", "Economics and Finance") revealed two main groups of potential Master's degree students: students with Bachelor's degree and working youth. The authors single out the leading type of motivation of this group of potential undergraduates which is referred to as the motivation of "personal prestige". The results of this study may be useful for methodologists, teachers, and managers in the field of higher education for creation of successful online Master's degree programs in Economics. 
Shostak Egor V., Donskoy Dmitry Yu.

APPLICATION OF PROJECT-BASED AYD INVEYTIVE ACTIVITY IN DEVELOPMENT OF CREATIVE THINKING OF TECHNOPARK STUDENTS

Key words: project-based and inventive activity, technopark, drone engineering, competencies, outlook.

The article considers the role of project-based and inventive activity in the world and national education. The importance of development of technical creativity in the conditions of additional education is emphasized. The authors illustrate the role of project-based and inventive activity in development of creative thinking of students in additional education by "Aeroquantum" program (drone construction and drone design). The authors describe the methodology aimed at development of some universal competencies and focused on expanding education and horizons of the student, with the inclusion of design and inventive activity at all stages of its implementation - from the origin of the idea to its practical implementation. An experimental program developed on a modular basis is described. The final goal of this study is to form students' universal and subject-related competencies in the main areas: programming of microcontrollers, flight operation of unmanned aircraft systems, etc. As a result of the pedagogical experiment, the following tasks were solved: a project "Drone construction" was developed, with subsequent testing, using the "Aeroquantum" program. In conclusion, the article considers the relevance of technology of using projects and inventive activity in a group project, the main idea of which is independent distribution of students' roles in a team.

\section{Tolstikhina Elena V.}

DEVELOPMENT OF HUMAY CAPITAL

AND SOFT SKILLS OF UNIVERSITY STUDENTS

BY MEAYS OF VIRTUAL INTERYATIONAL

ACADEMIC MOBILITY (WITHIY THE COURSE

"FOREIGY LAYGUAGE -ENGLISH")

Key words: virtual mobility, international mobility,

English, soft skills of the 21st century.

In response to the challenges of 2020-2021, education is undergoing transformation in terms of its forms and content in an effort to preserve the quality of development of students' human capital. One of the difficulties faced by all higher education institutions is preservation of international academic mobility of students as a way to develop communication and soft skills. This article discusses the experience of Southern Federal University in implementation of a blended learning format using virtual or online international student mobility within the framework of a foreign language (English) course related to the development of students' human capital and communicative competence. Human capital theory is the key in defining educational goals, and the level of English proficiency is defined as highly necessary for the development of soft skills in the 21 st century. The paper also analyses the results of students' academic achievements after learning in the blended mode. 


\section{IEОРИЯ И METOAИКА ФИЗИЧЕСКОГО ВОСПИТАНИЯ, СПОРТИВНОЙ ТРЕНИРОВКИ, ПЗДОРОВИТЕЛЬНОЙ И АААПТИВНОЙ ФИЗИЧЕСКОЙ КУЛЬТУРЫ}


- Наумов И.В. Физическая купьтура и спорт как усповие формирования человеческого капитапа студентов 
УДК 378

DOI $10 .|8522 / 2658-6983-202|-5-90-100$

Натуркач М.В.

\section{МЕДИАДИСКУРС}

В ИНФОРМАЦИОННОМ

ПРОСТРАНСТВЕ

И НЕОБХОДИМОСТЬ

РАЗВИТИЯ

МЕДИАДИСКУРСИВНОЙ

КОМПЕТЕНЦИИ

СТУДЕНТОВ

Ключевые слова: информационное пространство, информационная среда, дискурс, медиадискурс, медиатекст, СМИ, медиаобразование.
Социум в современном мире пронизан информацией. Информационное пространство находится в постоянном движении, обусловливая и формируя основы общественной жизни. Как никогда актуальным становится и анализ взаимодействия вовлеченных субъектов, особенно на уровне социальных групп, власти. Условность границ в пространстве и времени делает возможным стремительное перемещение информации. К этому добавляются новые возможности в последующей ее передаче и обработке. В подобной ситуации сглаживаются социальные, языковых и иные стереотипы. В целом больше возможностей появляется для построения открытого общества и формирования свободного информационного пространства. В условиях расширения информационного пространства значительное влияние испытывают все участники общественной жизни современности.

Кроме того, на текущей стадии развития наук гуманитарного цикла отчетливо заметен интерес к специфике функционирования сферы массовой коммуникации. Данное обстоятельство можно объяснить тем фактом, что общество постепенно осознало колоссальную роль средств массовой информации в динамике и эволюции социальной жизни; не случайно СМИ уже достаточно давно получили название «четвертая власть». Повседневная деятельность во всем многообразии общественной жизни опосредованно корректируется, чему способствует активное развитие и трансформация традиционных массмедиа, в свою очередь, быстро воспринимающих стремительный рост высоких компьютерных технологий и имплементацию интернет-ресурсов. Сегодня медийный вербальный, аудиальный и визуальный контент является одной 
из наиболее распространенных форм порождения и накопления информационного массива. Медийный дискурс, в свою очередь, можно понимать как институциональную форму коммуникации, применяющую специфическую систему профессионально ориентированных знаков, обладающую своим подъязыком и собственными прагматическими задачами. Именно медийный дискурс на фоне происходящих трансформаций в общественной картине мира представляет наибольший научный интерес, особенно в аспекте медиаобразования. Медийная среда накладывается на информационную, искажает ее, ретранслируя ее тем образом, который выгоден тому или иному политическому либо общественному актору. Данные обстоятельства и детерминируют актуальность тематики настоящей статьи.

Прежде чем рассмотреть специфику функционирования современного информационного пространства и соотношение информационного и медийного пространства, следует очертить терминологические границы первого из обозначенных понятий. Как указано в "Толковом словаре по информационному обществу и новой экономике», информационное пространство представляет собой «интегральное электронное информационное пространство, образуемое при использовании электронных сетей». Приводится также и второе значение данного термина - «сферы в современной общественной жизни мира, в которых информационные коммуникации играют ведущую роль» (Информационное пространство, https:// information_society.academic.ru/138).

Данное определение информационного пространства возникло как результат научного осмысления категории «информационное общество»; термин начал активно употребляться в 1960-х гг. в японских и американских исследованиях, посвященных выявлению роли знаний в прогрессе человечества. В научный оборот понятие информационного пространства было введено Ю. Хаяши, Т. Умесао и Ф. Махлупом. Японские социологи О. Кишида и Й. Масуда указывали, что информационное пространство не имеет региональных границ и характеризует информационную эпоху (Masuda, 1983). В последующем в научных кругах категория «информационное пространство» использовалась С.Э. Зуевым, О.В. Кедровским, А.В. Манойло, С.А. Модестовым, А.И. Ненашевым, Г.Г. Почепцовым, С.П. Расторгуевым и многими другими известными исследователями. Несмотря на обилие исследований, посвященных данному феномену, его дефиниция до сих пор не разработана. В частности, в философском словаре под ред. И.Т. Фролова представлено два термина: информация - как сведения, независимые от формы их представления, и пространство - как понятие, которое характеризует взаимное расположение сосуществующих объектов (Философский словарь, 2001, с. 356). Совокупность данных категорий порождает систему взаимодействия субъектов и объектов окружающей среды, связанных посредством потребления данных. Именно так можно представить широкое понимание информационного пространства. В некоторых источниках данное понятие трактуется достаточно узко. Кембриджский толковый словарь, к примеру, интерпретирует его как «место, где можно получить некую информацию, как правило, веб-сайт» (Information space, https://dictionary. cambridge.org/us/dictionary/english/ information-space).

Анализ словарных источников и литературы по вопросу дефинирования 
термина показал, что все определения можно разделить на ориентированные на технические науки и гуманитарные. К примеру, лаборатория искусственного интеллекта Массачусетского технологического института представила следующее толкование: информационное пространство - тип структурирования информационного массива, система информационных объектов (Information space, http:// www.ai.mit.edu/projects/infoarch/jair/ jair-help.html). Гуманитарные определения сходятся в том, что информационное пространство представляет собой совокупный результат семантической деятельности человечества, «мир имен и титулов», сопряженный с онтологическим миром. Информационное пространство, являющееся первичным понятием, не может быть точно определено и устанавливается как диалектическая оппозиция материальному, физическому, объектному пространству. В книге «Информационное пространство: основа для обучения в организациях, учреждениях и культуре» М. Бойсот описывает информационное пространство как концептуальную основу или инструмент для изучения того, как знания и информация кодифицируются, абстрагируются и распространяются в рамках социальной системы (Boisot, 1995).

Информационное пространство можно представить в качестве совокупности информационных ресурсов, информационных систем и коммуникационной среды (каналов). В исследованиях А.В. Манойло представлена аналогичная универсальная модель информационного пространства: по мнению ученого, информационное пространство состоит из информационного поля, информационных потоков и массмедиа как каналов коммуникации (Манойло, 2003, с. 14). Б.Н. Лозовский, в свою очередь, приходит к следующему умозаключению о компонентах информационного пространства: 1) выступающая реципиентом информации, транслируемой через каналы коммуникации, аудитория; 2) определенная система технологий телекоммуникации (особая телекоммуникационная инфраструктура); 3) международное информационное и технологическое взаимодействие (Лозовский, 2004).

Субъектами информационного пространства в рамках данной модели являются производители контента, а объектами, соответственно, - потребители информации. Среди групп потребителей указываются не только рядовые представители зрительской и читательской аудитории, но и публичные деятели, общественные лидеры, ньюсмейкеры в самых разных сферах как в мире политики, науки, производства, рекламы, так и в шоу-бизнесе, мире моды, среде богемы, деятелей высокой культуры, театра, кино.

Из вышесказанного следует, что информационное пространство несет крайне важную функциональную нагрузку. Функциональный спектр информационного пространства также не унифицирован в современных научных публикациях. В.Е. Макаров в монографическом исследовании приводит следующие функции информационного пространства: интегрирующая, коммуникативная, актуализирующая, геополитическая, социальная. Говоря о сущности интегрирующей функции, можно указать, что она сводится к формированию информационным пространством человеческой деятельности и ее субъектов (людей, социальных групп, государств) в единую пространственно-коммуникативную и социокультурную среду. В свою очередь, под коммуникативной функцией автор понимает создание среды мобильной 
коммуникации, реализуемой с целью информационного обмена. В анализе актуализирующей функции можно выделить акцент на важности всех субъектов деятельности и их интересов. Соответственно, геополитическая функция указывает, что динамические процессы, происходящие в информационном пространстве, порождают собственные ресурсы, коренным образом изменяющие ценность традиционных ресурсов системы геополитических отношений. Геополитическая функция логически обусловливает функцию социальную, сущность которой такова: информационное пространство меняет характер и содержание социально-политических отношений во множестве сфер - политической, культурной, научной, религиозной (Макаров, 2013, с. 100).

Как можно заметить из всего вышесказанного, центральным понятием в анализе сообщений, поступающих в информационное пространство, является термин «медийный дискурс» (мы также становимся свидетелями неоднократного отождествления двух данных категорий). Следовательно, медиадискурс представляет интерес как с точки зрения каналов коммуникации, протекающей в информационном пространстве, так и с точки зрения среды, создаваемой в информационном пространстве.

Дискурс можно интерпретировать как специфическую сферу общения, набор жанров и текстов, эмоциональный и информационный обмен, который приводитк оказанию воздействия, переплетению коммуникативных стратегий, вербальных и невербальных сообщений в практике общения. Размытость определения дискурса приводит к тому, что и термин «медийный дискурс» также не является четко очерченным. Многие исследователи отрицают правомерность употребления такого термина, поскольку, по их мнению, он не может считаться научно обоснованным, так как медийный дискурс не отличается гомогенностью и обладает прототипическими характеристиками, выступающими универсальными и тем не менее не характерными для других типов дискурса.

По нашему мнению, медийный (или массмедийный) дискурс, несмотря на свое жанровое разнообразие и изменчивость во времени, все же обладает некоторыми чертами, не присущими другим типам дискурса. На современном этапе развития общества и коммуникации масс-медийный дискурс является основным источником формирования социальных установок, общественных суждений, паттернов поведения, которые впоследствии определяют и индивидуальные действия. Медийный дискурс по-своему вербализирует ментальность, обладает специфическим способом интерпретации окружающей действительности, в результате чего конструируется особая реальность.

Дискурс неразрывно связан с общественными отношениями, поскольку не только создается ими, но и влияет на них. Медийный дискурс является специфической разновидностью дискурса, поскольку имеет ориентацию на собственные, присущие только ему цели. Исследование медиадискурса породило понятие медиатекста; возникновение в научных исследованиях данного термина связано с существенными изменениями характера коммуникативных процессов, отражающие мощное воздействие современных СМИ и на информационную среду, и на окружающую действительность в целом. Медиатекст можно трактовать, во-первых, в его универсальном, классическом значении - так тип текста; вовторых, как совокупный продукт мас- 
совой коммуникации. В пространстве массмедиа текст начинает функционировать по-иному. Появляются иные значения, оттенки смысла. Нюансы смыслов по-разному реализуются в системе языка, не ограничиваясь границами знаковой системы. Медиатексты, таким образом, представляют собой наполнение современной информационной среды. Сама же информационная среда кардинально меняется под воздействием среды медийной.

Подсистемами информационного пространства являются СМИ, понимаемые как совокупность групп аудитории и редакционных организаций, а также создаваемые ими информационные продукты. СМИ стали существенно видоизменять и расширять информационную среду уже с момента своего появления; изменились также способы, скорость и масштабы трансформации информационного пространства. Переходы от традиционного вещания и печати к спутниковому, цифровому, онлайн-транслированию последовательно приводили к расширению аудитории и увеличению степени воздействия на нее.

В ходе научных исследований тщательно рассматриваются всевозможные каналы медиакоммуникации, к которым относят как официально зарегистрированные СМИ (электронные, печатные, аудиовизуальные), так и неофициальные медийные каналы. Существует точка зрения о том, что именно официальные СМИ способны существенно изменять информационную среду, а коммуникация через неофициальные каналы во множестве случаев стихийна, создаваемые ею образы сложны и неоднородны. Однако ряд текущих тенденций опровергает данное положение. Все чаще именно неофициальные СМИ опосредуют глобальный массив информации и наделяют ее стойкой модальностью, выступая, таким образом, действенным инструментом оказания влияния на массы. Ряд исследователей СМИ отмечает, что деятельность государственных массмедиа до сих пор носит преимущественно пропагандистский характер. С другой стороны, множество исследователей указывает, что, хотя информационная деятельность государственных СМИ явно способствует искусственному формированию нужных позитивных образов, все же и новостные сообщения, поступающие из негосударственных СМИ, не всегда достаточно объективно и полно отражают существующую реальность.

Помимо параметра массовости, информационное пространство, ретранслируемое СМИ, отличается следующими фундаментальными характеристиками:

1. Глобализация: тенденция к слиянию телевизионных компаний и их объединению в конгломераты позволяет им трансформироваться в крупнейших, глобальных поставщиков информации.

2. Специализация и таргетирование: расслоение общества в результате возникновения все большего количества институтов и организаций СМИ привели к расслоению информационной среды; СМИ переключились на определенные аудиторные ниши.

3. Подверженность влиянию со стороны технологий: как и в большинстве других сфер, современные возможности технологий и их эффективное применение в значительной степени определяют характер информационной среды.

4. Господство в глобальном информационном пространстве определенных стран.

5. Регулирование работы СМИ: СМИ подвергаются критике со стороны 
общественности за свое неэтическое содержание и пагубное влияние на общество, проявляющееся прежде всего в социальной отчужденности, развращении молодежи, агрессии; урегулирование медиасферы, в свою очередь, стало необходимым для нивелирования негативного воздействия.

6. Преобладание коммерческих факторов над культурными.

Можно также сказать, что фактор глобальных СМИ определяет векторы культурного развития. В большой степени и существование самой реальности также обусловлено глобализацией СМИ и их влиянием. Сегодня можно обоснованно говорить о подмене реальности виртуальностью. Сознание человека, его духовный мир, ценности духовного плана и социальные связи могут в большой степени определяться влиянием виртуального измерения окружающего мира. Происходит перестройка психофизиологической системы человека. Виртуальный дизайн, целенаправленно или нет, «перестраивает» человека. Будучи лишь одним из измерений, виртуальное пространство приучает по-новому получать информацию. Логические конструкции уступают место виртуальным визуальным образам и энергетическим «квантам» (Миронов, 2005, с. 67).

Изучение взаимосвязи между информационным обществом и средствами массовой информации дает основания говорить о появлении массмедиа нового типа. Здесь на первый план выходят три основных аспекта. В первую очередь, следует отметить появление новых возможностей и наряду с этим ресурсов массмедиа, что основывается на развитии информационно-коммуникационных технологий и интернета на современном этапе. Вторым важным аспектом следует считать очевидную интернетизацию средств массовой информации традиционного плана. Третий аспект - новые массмедиа или новые средства массовой коммуникации (Сергеев, 2009, с. 120). Новая информационная среда оказывает возрастающее влияние и на языковой уровень сознания: помимо линейной, формируется гипертекстовая структура языковой системы.

Согласно Е.Ю. Сергееву, публичная сфера на национальном уровне (информационная среда) является частью мировой. Она включаются в мировую информационную среду, и таким образом создается глобальный публичный ареал. Помимо подобной глобализации, мы также имеем дело с обратным процессом - фрагментацией аудитории, позволяющей направлять нужный тип ресурсов для удовлетворения специализированного типа потребностей потребителей информации (там же, с. 121-122).

Можно сказать, что на современном этапе развитие всемирной информационной среды находится под влиянием двух тенденций: с одной стороны глобализации, с другой - специализации и регионализации. Массовость как основная черта, приписываемая СМИ, теряет свою релевантность; массовая рассылка одинаковых сообщений сменяется на трансляцию специфичных сообщений в адрес однородного сегмента целевой аудитории. В качестве причин подобного процесса можно назвать как множественность сообщений и источников, так и склонность нового поколения аудитории к самостоятельному выбору специализированного, кастомизированного контента. Происходит сегментация информационной медийной среды потребителями. Массмедийная аудитория стремится выбирать точечные сообщения. Таким образом, между отправителем информации и ее получателем углубляется 
взаимодействие. Можно говорить даже об индивидуализации отношений в информационной среде. Данное обстоятельство можно проиллюстрировать феноменом использования кукиз, технология которых позволяет персонализировать выдачу контента потребителям на основании их деятельности в интернете.

Современные СМИ основаны на интерактивном диалоге с аудиторией (Сергеев, 2009, с. 122). Многие из них получают рейтинги во многом благодаря интерактивной политике. Проводятся интернет-сессии, онлайн-мосты. Самые активные массмедиа в этом плане имеют фронтмэнами одиозных ведущих. Часто за счет противоречивых фигур создается аналогичная кликбэйту в интернете ситуация и в классических СМИ. Киты медиа стараются в цифровом мире использовать и модные каналы связи с обществом, привлекая к себе сегменты увлеченной и пользующейся технологиями молодежи. Успешность информационной политики сегодня - это во многом успешность политики интерактивной. Могут создаваться в угоду потребителю виртуальные клубы зрителей, читателей. Коммуникация может проходить в виде чатов между пользователями, ведущими СМИ (в зарубежной литературе данное понятие именуется new media). $\mathrm{K}$ new media можно отнести широкий спектр современных цифровых платформ и социальных сетей (Instagram, Tik-Tok). Выделяют также видеохостинги и видеоресурсы (Twitch, Rutube List). Актуальными являются зарубежные и отечественные подкасты. У многих популярностью пользуются различные информационно-развлекательные ресурсы ("Медуза», The Question, The Village). Все это помимо личных блогов в пространствах Facebook, Clubhouse и т.д. Не стоит недооценивать и мессен- джеры (WhatsApp, Telegram). Важно помнить, что эти же ресурсы используются и манимейкерами. Они являются средством общения редакторов СМИ, представителей органов власти и часто из-за массовости в первую очередь находятся под ударами и угрозой отключения, особенно при социальных волнениях, когда возможно их использование нечестивыми политиками, фабриками фэйк-ньюс.

Возможность передачи по сети любого информационного сегмента и его видоизменения создает множество угроз. Сегодня очевидна уязвимость перед целенаправленным манипулированием. Часто текст становится средством введения в заблуждение. Образ, создаваемый СМИ, - это не безобидный папарацци. Все чаще мы имеем дело с нарушением прав на приватность информации. Случаи разглашения конфиденциальной информации, международных и дипломатических документов из-за соображений свободы слова и совести часто переносят возникающие скандалы на международный уровень, где степень сложности возникающих проблем провоцирует еще большие социальные конфликты, откликающиеся глобально. В подобное коммуникативное поле может добавляться допущение различных форм оскорбления личности, власти, общественных институтов. Достижения информационных технологий, наряду с изменениями геополитического баланса, оказывают воздействие на развитие медиапространства.

Функционирование коммуникативных законов важно отслеживать. Анализ составляющих часто помогает правильно оценивать информационную ситуацию. Первичные и вторичные коммуникативные процессы структурируют коммуникативное пространство. С процессом перво- 
начальной постановки информации, реальной информацией, общением в определенной среде имеют дело первичные процессы. Когда же дело касается обсуждения и распространения, это связано с работой вторичных процессов. Продолжительность коммуникативного процесса во вторичных процессах обусловливает эффективность первичного коммуникативного процесса (Почепцов, 1994). Очевидно, что СМИ нацелены на достижение этого долгоиграющего эффекта, и привлекаться могут все средства для расширения границ информационного пространства. Манипулировать сознанием средства массовой информации могут, заимствуя методы, привлекая смешение жанров. Транслирование культуры становится, таким образом, не единственной целью СМИ, которые выступают и как средство прямого воздействия на настроения как с помощью опосредования действительности, так и с помощью самой культуры.

Мышление, основанное на социальных, культурных, возрастных стереотипах, влияет и на то, каким образом информация опосредуется аудиторией. Дигитализация, клиповость мышления, восприятие окружающей действительности и массмедиа как ее составляющей в упрощенных схемах могут делать потребление информационного контента поверхностным.

. Следовательно, современная информационная среда состоит из упрощенных конструктов, смысл которых упрощается преимущественно массмедиа. Все чаще встречающиеся в научных публикациях и публицистических материалах термины «информационная перегрузка», «цифровой детокс», «фейк-ньюс», «синдром информационной усталости», "твиттеризация культуры», «клиповое мышление», которые отображают одну важную тен- денцию эволюции информационной среды: человек не способен анализировать массивный хаотичный поток поступающей информации, выбирая наиболее запоминающиеся факты и небольшие отрывки контента; мы также разделяем точку зрения ряда исследователей о том, что слишком объемный информационный массив поступает в бессознательное индивида, минуя уровень сознания.

СМИ при создании нужной им информационной среды эксплуатируют базовые потребности и эмоции. На наш взгляд, массмедиа также оказались способны формировать ложное чувство осведомленности у аудитории, когда ее представителям кажется, что, прослушивая большое количество новостных сообщений и выбирая их, как им кажется, самостоятельно, они получают довольно полное представление о текущих процессах окружающей реальности. Тем не менее неоднократно доказано, что массмедиа культивируют модели поведения, альтернативные тем, которые признаны классическими институтами воспитания, что, в свою очередь, существенно деформирует взгляды и мнения людей. В качестве примера приведем сообщения об инцидентах, катастрофах, насилии, что может как вызывать нужные эмоции у потребителей контента, так и обеспечивать сенсибилизацию. В этом случае аудитория перестает воспринимать данные сообщения как трагические. Возможно появление другого сценария отношения - как к захватывающему сюжету. Формируется отношение будничности или же сенсационности.

Из всего вышесказанного следует, что манипулирование возможно благодаря поверхностности, некритичности мышления, склонности к эмоциональному наполнению индивидуального информационного поля. 
Логическое мышление также оказывается задействованным в манипулятивных тактиках: по своей внешней форме материал СМИ выстраивается логично, однако псевдологика скрывает ключевую идею. Ассоциативность мышления используется для формирования требуемых отношений. Сознание потребителя контента наводняется нужными метафорами, мифами. Так возможно навязывание стереотипов и внедрение новых идей. Поступление, запоминание, хранение, воспроизведение полученной информации строятся на стереотипах, ассоциациях, внушаемых посредством дробления и многократного повторения информации. Как видим, процесс модификации информационной среды за счет СМИ является исключительно сложным и противоречивым и ведет к неоднозначным последствиям. К числу таких последствий относятся стандартизация и униформизация компонентов информационной среды, гибридизация и креолизация жанров и типов текстов.

Развитие приемов формирования информационного пространства настолько существенно, что оно уже на текущий момент приводит к кардинальным переменам в политической и военной сфере. В зарубежных и отечественных публикациях все чаще стал появляться термин «информационная война», отражающий революционные преобразования в сфере политического противоборства именно в пространстве информационной среды. Можно сказать, что информационная война - это форма борьбы сторон, представляющая собой использование специальных (политических, экономических, дипломатических, военных и иных) методов, способов и средств для воздействия на информационную среду противостоящей стороны и защиты собственной. Исследователи довольно давно основной причиной появления информационных войн стали называть активное развитие средств массовой коммуникации.

Большинство людей в качестве основного источника получения информации может назвать именно описанную нами выше виртуальную медийную реальность, сформированную и транслируемую медиадискурсом. В своей "упаковке» медиатекст формирует представления, ранжирует факты, предоставляя (иногда навязывая их уже на подсознательном уровне) идеологические, когнитивные и аналитические услуги в виде интерпретаций, комментариев, эмоционально-образного осмысления реалий. Компоненты массовой коммуникации, таким образом, выступают важным инструментом идеологической машины, будь то этап формирования повестки дня, создания доктрины с нуля или же развитие и эксплуатация сложившихся схем отношений в социуме. Это пронизывает всю иерархию социальноэкономической системы. Государственная пропаганда и негосударственные структуры широко применяют возможности массмедиа в своих целях. Определенные этапы политического, социального, экономического, религиозного, культурного строительства невозможны без использования средств медиапространства. Воспитание современного участника социума также невозможно без разумного и опосредованного использования материалов массмедийного потенциала. Это не отменяет пагубную роль пропаганды в некоторых обществах, где манипулирование используется неумело и без учета развития общества.

Все новые формы медиа появляются в последнее время. Привлечение их ресурсов на разных уровнях дает ощущение динамики и прогресса, что ча- 
сто в связи с активизацией общественно-политической деятельности в мире оттеняет явные промахи идеологической работы. В эру глобальной информатизации СМИ язык медиадискурса на уровне психологии, лингвистики и смежных наук (психолингвистики, когнитивной лингвистики) активно изучается. Работы в области дискурсивного анализа, текстолингвистики способны дать новые варианты применения технологий глобальных медиа.

Исходя из вышеизложенного, с учетом важности всех вышеперечисленных аспектов, особенно актуальным становятся понятия «медиаобразование» и "медиадискурсивная компетентность личности международника». Г. Максимова в связи с этим указывает на тот факт, что людям, находящимся в пространстве информационной среды, приходится осознанно и тщательно выстраивать процесс восприятия, понимания и порождения различной информации как составляющих медиадискурсивной компетентности личности (Максимова, 2005, с. 132). В теоретико-прикладном плане данные вопросы решаются в вузовской практике в области медиаобразования: модели, методы, технологии, создаваемые в вузовской среде, могут эффективно поспособствовать свободному выбору направлений воспитательной, идеологической работы. Компетенции, формируемые посредством привлечения медиаматериалов, идей, сценариев и сюжетов СМИ, востребованы на разных этапах профессиональной подготовки специалистов. Транслируемые посредством медиа отношения и позиции важны в выстраивании государственной политики в области образования и воспитания. В целом информационное пространство - важный элемент жизни общества. Именно в вопросах формирования мировоззренческих позиций, патриотических убеждений широко используется потенциал медиапространства. Глубокое осмысление актуальных экономических, социальных, культурных вопросов достигается при анализе материалов массмедиа. Системное использование как наработанных подходов, так и самих материалов медиадискурса сегодня критически важно.

\section{תumepamypa}

1. Информационное пространство. URL: https:// information_society.academic.ru/ 138 .

2. Лозовский Б.Н. Журналистика: краткий словарь. Екатеринбург: Изд=во Урал. ун-та, 2004.

3. Макаров В.Е. Политические и социальные аспекты информационной безопасности. М.; Таганрог: С.А. Ступин, 2015.

4. Максимова Г. Технологии медиаобразования // Высшее образование в России. 2005. № 6. C. 131-134.

5. Манойло А.В. Государственная информационная политика в особых условиях. М.: МИФИ, 2003.

6. Миронов В.В. Философия: учебник. М.: Норма, 2005.

7. Почепцов Г.Г. Послекоммуникативные процессы // Рациональность и семиотика дискурса. Киев: Наукова думка, 1994.

8. Сергеев Е.Ю. Средства массовой коммуникации в условиях глобализации // Общество. Среда. Развитие. 2009. № 1. С. 117-126.

9. Философский словарь / под ред. И.Т. Фролова. М.: Республика, 2001.

10. Boisot, M.H., 1995. Information Space: A framework for learning in organizations, institutions and culture. London: Routledge, 1995.

11. Information space. URL: https://dictionary.cambridge.org/us/dictionary/english/informationspace.

12. Information space. URL: http://www.ai.mit.edu/ projects/infoarch/jair/jair-help.html.

13. Masuda, Y., 1983. The Information society as postindustrial society. Washington: World Future Society.

\section{Reference}

1. Information space. Available at: https://information_society.academic.ru/138. (rus)

2. Lozovsky, B.N., 2004. Journalism: a short dictionary. Yekaterinburg: Publishing house of the Ural University. (rus)

3. Makarov, V.E., 2015. Political and social aspects of information security. Moscow; Taganrog: S.A. Stupin. (rus)

4. Maksimova, G., 2005. Technologies of media education. Higher Education in Russia, 6: 131-134. (rus) 
5. Manoylo, A.V., 2003. State information policy in special conditions. Moscow: MEPhl. (rus)

6. Mironov, V.V., 2005. Philosophy: textbook. Moscow: Norma. (rus)

7. Pocheptsov, G.G., 1994. Post-communicative processes. Rationality and semiotics of discourse. Kiev: Naukova Dumka. (rus)

8. Sergeev, E.Yu., 2009. Mass communication media in the conditions of globalization. Society. Environment. Development, 1: 117-126. (rus)

9. Frolov, I.T. (Ed.), 2001. Philosophical dictionary. Moscow: Republic, 2001. (rus)
10. Boisot, M.H., 1995. Information Space: A framework for learning in organizations, institutions and culture. London: Routledge, 1995.

11. Information space. Available at: https://dictionary. cambridge.org/us/dictionary/english/informationspace.

12. Information space. Available at: http://www.ai.mit. edu/projects/infoarch/jair/jair-help.html.

13. Masuda, Y, 1983. The Information society as postindustrial society. Washington: World Future Society. 


\title{
ПРАВИЛА ДЛЯ АВТОРОВ ЖУРНАЛА
}

\author{
«Мир университетской науки: \\ купьтура, образование»
}

1. Журнал «Мир университетской науки: культура, образование» включен в Перечень ведущих рецензируемых научных журналов, рекомендованных ВАК РФ для публикации основных результатов диссертационных исследований на соискание ученых степеней доктора и кандидата наук по педагогике и психологии (дата включения в Перечень 01.12.2015, № 678).

2. Журнал публикует статьи по широкому спектру теоретических и прикладных проблем в сферах методологии и теории образования, истории педагогики, воспитания и изучения личности, информационных технологий в образовании, специальной педагогики, профессионального образования, повышения квалификации специалистов, компетентностного подхода в образовании, практической психологии образования, образования взрослых, управления образовательными системами всех уровней и т.д. К публикации принимаются оригинальные материалы, содержащие результаты научных исследований.

3. Объем статьи должен быть не менее 10 и не более 18 страниц. Текст набирается в соответствии с правилами компьютерного набора с одной стороны белого листа бумаги стандартного формата (A4).

4. Для кандидатов наук и авторов, не имеющих научной степени, необходимо предоставление рецензии за подписью доктора наук по специальности (педагогика или психология).

5. Технические требования к оформлению статей приведены на сайте журнала по адресу: http://woasfedu.ru.

6. Редакционный совет и редколлегия производят отбор поступивших материалов и распределяют их по рубрикам. Вводится специальная рубрика «Научно-педагогический поиск аспирантов». Плата с аспирантов за публикацию статей не взимается. Редакционная коллегия оставляет за собой право на редактирование статей с сохранением авторского варианта научного содержания. В случае необходимости редколлегия вступает в переписку с авторами по электронной почте и может обратиться с просьбой о доработке материалов. Статьи, не соответствующие перечисленным требованиям, не публикуются и почтовой пересылкой не возвращаются.

7. Авторские гонорары не выплачиваются.

8. Дополнительные условия публикации высылаются по запросу.

Адрес редколлегии:

344006, г. Ростов-на-Дону, ул. Большая Садовая, 105/42 Южный федеральный университет.

Ответственный секретарь - Сохиева Наталья Петровна

Тел./факс: (863) 240-47-08, e-mail: n2404708@yandex.ru

Принимается подписка:

Журнал выходит 10 раз в год

Подписной индекс 47204 по Каталогу Роспечати. Подписка принимается в любом отделении связи России. Базовая стоимость подписки на полугодие - 600 руб.; окончательную цену устанавливают региональные управления почтовой связи.

Можно оформить подписку в редакции.

В редакции также принимается подписка на электронную версию журнала (на полугодие - 500 руб., на год - 1000 руб.). Электронный выпуск в формате PDF доставляется на указанный вами e-mail.

Архив журнала в печатном и электронном виде можно приобрести в редакции.

По всем вопросам (подписка, публикации) просьба обращаться к ответственному секретарю журнала Наталье Петровне Сохиевой по электронной почте n2404708@уandex.ru. 
Научно-педагогическое издание

\section{МИР УНИВЕРСИТЕТСКОЙ НАУКИ: КУЛЬТУРА, ОБРАЗОВАНИЕ}

\section{I. № 5}

$\begin{array}{ll}\text { Редактор } & \text { Н.В. Бирюкова } \\ \text { Компьютерная верстка } & \text { Е.А. Солоненко } \\ \text { Дизайн обложки } & \text { О.Ф. Жукова } \\ \text { Перевод } & \text { А. Андриенко }\end{array}$

